\title{
Perbedaan Hasil Belajar Siswa dengan Model Pembelajaran Think Talk Write dan Pembelajaran Ekspositori di Kelas VII SMP Negeri 15 Kota Bengkulu
}

\author{
${ }^{1}$ Elsa Putri Gusvarini, ${ }^{2}$ M. Fachruddin S, ${ }^{3}$ Effie Efrida Muchlis \\ ${ }^{1,2,3}$ Program Studi Pendidikan Matematika JPMIPA FKIP Universitas Bengkulu \\ email : 1elsaaputri@yahoo.com, ${ }^{3}$ effie_efrida@yahoo.com
}

\begin{abstract}
Abstrak
Penelitian ini bertujuan untuk mengetahui perbedaan hasil belajar siswa antara model pembelajaran think talk write dan pembelajaran ekspositori di Kelas VII SMP Negeri 15 Kota Bengkulu. Populasi pada penelitian ini adalah siswa kelas VII SMP Negeri 15Kota Bengkulu tahun ajaran 2016/2017. Sampel diambil dengan teknik purposive samplingsehingga diperolehkelas VII A sebagai kelas eksperimen dan VII B sebagai kelas kontrol. Teknik pengumpulan data menggunakan tes. Instrumen penelitian berupa posttest berbentuk soal uraian. Instrumen posttest di uji cobakan di kelas uji coba, lalu dilakukan analisis dengan uji validitas (empiris), uji reliabilitas, uji tingkat kesukaran dan uji daya pembeda soal.Hasil posttest menunjukkan kelas kontrol dengan jumlah siswa 33 orang, memperoleh rata-rata hasil belajar siswa 60,70 dan varians 119,04. Sedangkan kelas eksperimen dengan jumlah siswa 32 orang, memperoleh rata-rata hasil belajar siswa 75,88 dan varians 70,71Teknik analisis data yang digunakan adalah uji prasyarat analisis yang terdiri dari uji normalitas dan uji homogenitas. Kemudian pengujian hipotesis menggunakan uji-t satu pihak. Berdasarkan perhitungan uji-t satu pihak dengan taraf signifikan 5\% dan derajat kebebasan 63 diperoleh $t_{\text {hitung }}=6,269>t_{\text {tabel }}=1,998$ maka dapat disimpulkan bahwa terdapat perbedaan yang signifikan antara rata-rata hasil belajar siswa dengan menggunakan model pembelajaran think talk write dan pembelajaran ekspositori di kelas VII SMP Negeri 15 Kota Bengkulu.
\end{abstract}

Kata Kunci:hasil belajar, think talk write, ekspositori

\begin{abstract}
The purpose of this study was to investigate the differences of learning outcomes ability between students given model of learning ThinkTalk-Write with Expository in first grade of SMP Negeri 15 Bengkulu city. The population was first grade of SMP Negeri 15 Bengkulu city in the academic year 2016/2017. Then by using purposive sampling technique, VII A was selected as the experimental class and VII B as the control class. Data collecting technique was test. The instrument was essay posttest. The posttest instrument had tested in a trial class, then analyzed its validity, reliability, level of difficulty and discrimination power. The results showed that 33 students of control class got the scores about 60,70 with variances 119,04 while 32 students of experimental class got 75,88 with variances 93,08. Data analysis was performed by precondition testing analysis which consisted of normality and homogeneity testing. Then, the hypothesis was tested by using one side t-test. Based on the calculation of two side $t$-test with 5\% of significant level and 63 of independent degree resulted $t_{\text {count }}=6,269>$ $t_{\text {table }}=1.998$ then it was concluded that in the first grade of SMP Negeri 15 Bengkulu city, there is a signignificant difference between learning outcomes of students who were given model of learning Think-Talk-Write and than the students who were given model of learning Expository.
\end{abstract}

Keyword :learning outcomes. think talk write, expository 


\section{PENDAHULUAN}

Pada era perkembangan ilmu pengetahuan dan teknologi seperti sekarang, matematika memiliki peranan penting. Oleh karena itu, matematika menjadi mata pelajaran yang diajarkan pendidikan dasar sampai ke perguruan tinggi. Tanpa disadari, matematika juga tidak terlepas dari kegiatan sehari-hari yang dilakukan manusia. Untuk meningkatkan mutu sumber daya manusia dalam menghadapi perkembangan ilmu pengetahuan dan teknologi maka diperlukan perbaikan dalam proses pembelajaran matematika di sekolah sehingga membantu untuk mencapai hasil belajar yang ditetapkan .

Berdasarkan hasil wawancara yang dilakukan dengan salah satu guru matematika di SMP Negeri 15 Kota Bengkulu diketahui bahwa hasil belajar siswa masih rendah. Hal ini terlihat dari banyak siswa mendapatkan nilai dibawah KKM. Selain itu, diperoleh juga bahwa siswa masih kesulitan untuk menyelesaikan soal-soal yang berbeda dengan yang dilakukan guru, sehingga hal tersebut berakibat kepada rendahnya hasil belajar siswa. Dan berdasarkan hasil observasi di kelas terlihat bahwa proses pembelajaran masih didominasi oleh guru. Sehingga siswa kurang terlibat dalam proses pembelajaran.

Gambaran dari hasil belajar siswa dapat dilihat dari kemajuan belajar yang dilihat dari evaluasi yang diberikan oleh guru. Guru merupakan salah satu unsur yang dapat mempengaruhi keberhasilan proses pembelajaran di kelas. Sehingga diperlukan variasi dalam proses pembelajaran yang dilakukan oleh guru untuk membantu siswa memaksimalkan hasil belajar. Salah satu variasi yang dapat dilakukan guru adalah dengan adanya model pembelajaran yang tepat yang membuat siswa terhindar dari jenuh ketika belajar

Salah satu alternatif yang dapat digunakan untuk mengatasi permasalah tersebut adalah model pembelajaran think talk write. Model pembelajaran think talk write pada dasarnya dibangun melalui proses berpikir, berbicara dan menulis (Yamin dan Ansari, 2012: 84). Kemampuan talking dan writing pada model pembelajaran ini mampu membantu untuk kemampuan pemahaman konsep. Melalui model pembelajaran think talk write diharapkan dapat membantu siswa dalam prose pembelajaran sehingga dapat meningkatkan hasil belajar siswa di sekolah.

Berdasarkan uraian diatas maka rumusan masalah pada penelitian ini adalah "Apakah terdapat perbedaan hasil belajar siswa yang signifikan antara model pembelajaran think talk writedan pembelajaran ekspositori di Kelas VII SMP Negeri 15 Kota Bengkulu?

Adapun tujuan yang ingin dicapai pada penelitian ini adalah "Untuk mengetahui perbedaan hasil belajar siswa antara model pembelajaran think talk write dan pembelajaran ekspositori di Kelas VII SMP Negeri 15 Kota Bengkulu".

\section{A. Model Pembelajaran Think Talk Write}

Model pembelajaran think talk write merupakan model pembelajaran yang diperkenalkan oleh Huinker \& Laughin. Secara etimologi, think diartikan dengan "berpikir", talk diartikan "berbicara". Sedangkan write diartikan sebagai "menulis".Think talk write adalah sebuah model pembelajaran yang dimulai dengan berpikir melalui bahan bacaan (menyimak, mengkritisi, dan alternative solusi), hasil bacaannya dikomunikasikan dengan presentasi diskusi dan kemudian membuat laporan hasil presentasi (Hamdayama, 2014: 217).

Langkah-langkah pembelajaran yang digunakan pada penelitian ini adalah langkahlangkah pembelajaran modifikasi dari Shoimin (2014: 214) yaitu:

a. Guru membagikan LKPD yang memuat soal yang harus dikerjakan oleh peserta didik serta petunjuk pelaksanaannya

b. Peserta didik membaca masalah yang ada dalam LKPD dan membuat cacatan kecil secara individu pada LKPD yang telah disiapkan tentang apa yang ia ketahui dan tidak ketahui dalam masalah tersebut. Ketika peserta didik membuat catatan kecil inilah akan terjadi proses berpikir (think) pada peserta didik. Setelah itu peserta didik berusaha untuk menyelesaikan masalah tersebut secara individu. Kegiatan 
ini bertujuan agar peserta didik dapat membedakan atau menyatukan ide-ide yang terdapat pada bacaan untuk kemudian diterjemahkan ke dalam bahasa sendiri

c. Guru membagi peserta didik dalam kelompok kecil yang terdiri dari 4 siswa. Guru mengelompokkan peserta didik secara heterogen berdasarkan kemampuan peserta didik. Setiap kelompok beranggotakan peserta didik berkemampuan tinggi, berkemampuan sedang dan berkemampuan rendah sehingga setiap kelompok memilik kemampuan yang sama

d. Siswa berinteraksi dan berkolaborasi dengan teman satu grup untuk membahas isi catatan yang telah dibuat secara individu (talk). Dalam kegiatan ini mereka menggunakan bahasa dan kata-kata yang mereka sendiri untuk menyampaikan ideide dalam diskusi. Selain itu peserta didik juga berdiskusi untuk mengisi LKPD pada tahap talk. Diskusi diharapkan dapat menghasilkan solusi atas soal yang diberikan

e. Dari hasil diskusi, peserta didik secara individu merumuskan pengetahuan berupa jawaban atas soal (berisi landasan dan keterkaitan konsep, model, dan solusi) dalam bentuk tulisan (write) dengan bahasa sendiri. Pada tulisan itu, peserta didik menghubungkan ide-ide yang diperolehnya melalui diskusi dan menuliskan pada LKPD

f. Perwakilan kelompok menyajikan hasil kelompok, sedangkan kelompok lain diminta untuk memberikan tanggapan

g. Kegiatan akhir pembelajaran adalah membuat refleksi dan kesimpulan atas materi yang dipelajari. Sebelum itu, dipilih beberapa atau satu orang peserta didik sebagai perwakilan kelompok untuk menyajikan jawabannya, sedangkan kelompok lain diminta memberikan tanggapan.

\section{B. Pembelajaran Ekspositori}

Ruseffendi (2006: 290) metode ekpositori adalah pembelajaran yang dimulai dari guru memberikan informasi secara ceramah kemudian guru menerangkan, mendemontrasikan suatu konsep, siswa bertanya, guru memeriksa paham atau tidak dilanjutkan dengan pemberian contoh soal dan diakhiri dengan siswa mencatat yang telah dijelaskan. Tujuan utama dari pembelajaran ekspositori adalah "memindahkan" pengetahuan, keterampilan, dan nilai-nilai kepada siswa (Dimyati dan Mudjiono, 2013:172). Melalui pembelajaran ekspositori berarti siswa akan mampu menerima materi sebanyak-banyaknya dengan waktu yang singkat karena siswa hanya menerima materi yang diberikan dan siswa tidak menemukan sendiri.

Langkah-langkah dalam menerapkan pembelajaran ekspositori yang digunakan pada penelitian ini menurut Sanjaya (2014: 185-190)

a. Persiapan (preparation)

Langkah ini berkaitan dengan mempersiapkan siswa untuk menerima pelajaran.

b. Penyajian (presentation)

Langkah penyajian merupakan langkah penyampaian materi yang telah dipersiapkan.

c. Korelasi (correlation) Langkah korelasi merupakan langkah dimana menghubungkan antara materi dan pengalaman siswa atau hal lainnya yang memungkinkan siswa dapat menangkap keterkaitan dalam struktur pengetahuan yang dimilikinya.

d. Menyimpulkan (generalization)

Langkah menyimpulkan merupakan langkah untuk memahami inti dari materi pelajaran yang telah disajikan.

e. Mengaplikasikan (aplication)

Langkah aplikasi ini dilakukan untuk melihat kemampuan siswa setelah menerima penjelasan dari guru.

\section{Hasil Belajar}

Hasil belajar merupakan kemampuan siswa yang diperoleh setelah melalui kegiatan belajar.Bloom dalam Sudjana (2009:22) secara garis besar membagi hasil belajar menjadi tiga ranah, yaitu ranah koginitif, ranah afektif, dan 
ranah psikomotorik. Tiga ranah tersebut diuraikan sebagai berikut :

1. Ranah Koginitif berkenaan dengan hasil belajar intelektual yang terdiri dari enam aspek, yakni pengetahuan atau ingatan, pemahaman, aplikasi, analisis, sintesis, dan evaluasi. Kedua aspek pertama disebut koginitif tingkat rendah dan keempat aspek berikutnya termasuk koginitif tingkat tinggi.

2. Ranah Afektif berkenaan dengan sikap yang terdiri dari lima aspek, yakni penerimaan, jawaban atau reaksi, penilaian, organisasi, dan internalisasi.

3. Ranah Psikomotorik berkenaan dengan hasil belajar keterampilan dan kemampuan bertindak. Ada enam aspek ranah psikomotoris, yakni gerakan refleks, keterampilan gerakan dasar, kemampuan perseptual, keharmonisan atau ketepatan, gerakan keterampilan kompleks, dan gerakan ekspresif dan interpretatif.

\section{METODE}

Desain penelitian yang dilaksanakan pada peneltian ini menggunakan posttest only control design dengan desain sebagai berikut :

Tabel 1Desain Penelitian

\begin{tabular}{|c|c|c|}
\hline Kelas & Perlakuan & Posttest \\
\hline $\begin{array}{c}\text { Eksperimen } \\
(\mathrm{E})\end{array}$ & $\mathrm{X}_{1}$ & $\mathrm{O}_{1}$ \\
\hline Kontrol (K) & $\mathrm{X}_{2}$ & $\mathrm{O}_{2}$ \\
\hline
\end{tabular}

Sumber : Sugiyono (2014: 76)

Keterangan :

$\mathrm{X}_{1}=$ perlakuan yang diberikan pada kelas eksperimen (model pembelajaran think talk write)

$\mathrm{X}_{2}=$ perlakuan yang diberikan pada kelas kontrol (pembelajaran ekspositori)

$\mathrm{O}_{1}=$ posttest yang diberikan pada kelas eksperimen setelah diberikan perlakuan

$\mathrm{O}_{2}=$ posttest yang diberikan pada kelas kontrol setelah diberikan perlakuan

Pada penelitian ini, populasi yang diambil yaitu siswa kelas VII SMP Negeri 15 Kota
Bengkulu tahun ajaran 2016/2017. Dan pemilihan sampel menggunakan teknik purposive sampling.Purposive sampling merupakan teknik pemilihan sampelberdasarkan kriteria tertentu. Kriteria yang digunakan yaitu kelas yang memiliki kemampuan relatif sama berdasarkan nilai rapor semester ganjil dan kelas tersebut diajar oleh guru yang sama. Melalui teknik pengambilan sampel tersebut maka diperoleh kelas sampel yaitu kelas VII A dan VII B. setelah kedua kelas sampel terpilih dilanjutkan dengan pemberian pretest pada kelas sampel. Berdasarkan pretest yang dilakukan pada kedua kelas, diperoleh nilai kelas VII $\mathrm{A}=27,67$ dan kelas VII $\mathrm{B}=26,01$. Dari nilai pretest tersebut dapat dilihat bahwa kedua kelas sampel memiliki kemampuan yang hampir sama karena nilai rata-rata kelas tersebut hampir sama. Penentuan kelas eksperimen dan kelas kontrol melalui undian sehingga diperoleh kelas VII A sebagai kelas eksperimen dan kelas VII B sebagai kelas kontrol.

Instrumen yang digunakan pada penelitian adalah soal tes yang berupa posttest untuk mengukur hasil belajar siswa. Teknik pengumpulan data pada penelitian ini menggunakan tes. Tes yang diberikan berupa soal posttest berbentuk soal uraian berdasarkan indikator pemahaman konsep.Soal posttest yang diberikan kepada siswa akan digunakan untuk memperoleh data hasil belajar siswa pada ranah kognitif yaitu kemampuan pemahaman konsep. Sebelum posttest diberikan kepada kelas sampel, terlebih dahulu dilakukan uji coba instrumen di kelas uji coba dengan analisis uji validitas, reliabilitas, taraf kesukaran dan daya pembeda soal.

Berdasarkan hasil uji coba instrumen dengan uji validitas, uji reliabilitas, taraf kesukaran soal dan daya pembeda soal terhadap 7 soal yang diuji cobakan sehingga 5 soal yang dapat digunakan pada penelitian ini sesuai dengan kriteria uji coba soal posttest.

Teknik analisis data yang digunakan untuk pengujian prasyarat analisis

a. Uji Normalitas

Uji normalitas yang digunakan adalah uji Kolmooforof_Smirnov Z pada SPSS

\section{b. Uji Homogenitas}


Uji homogenitas yang digunakan adalah uji $\mathrm{F}$.

\section{c. Pengujian Hipotesis}

Pengujian hipotesis menggunakan uji-t satu arah.Adapun hipotesisnya sebagai berikut :

$\mathrm{H}_{0}=$ tidak terdapat perbedaan yang signifikan antara rata-rata hasil belajar siswa dengan model pembelajaran think talk write dan pembelajaran ekspositori di kelas VII SMP Negeri 15 Kota Bengkulu

$\mathrm{H}_{1}=$ terdapat perbedaan yang signifikan antara rata-rata hasil belajar siswa dengan menggunakan model pembelajaran think talk write dan pembelajaran ekspositori di kelas VII SMP Negeri 15 Kota Bengkulu

\section{HASIL DAN PEMBAHASAN Hasil}

Penelitian yang dilakukan di SMP Negeri 15 Kota Bengkulu untuk mengetahui perbedaan hasil belajar siswa dengan Model Pembelajaran Think Talk Write dan Pembelajaran Ekspositori di SMP Negeri 15 Kota Bengkulu selama 6 pertemuan yaitu 5 pertemuan materi dan 1 pertemuan posttest. Pelaksanaan postestdilakukan untuk melihat perbedaan hasil belajar siswa kelas kontrol dan kelas eksperimen. Berikut ini adalah hasil posttest kelas kontrol dan kelas eksperimen.

Tabel 2Data Hasil Posttest

\begin{tabular}{|c|c|c|c|}
\hline Kelas & $\begin{array}{c}\text { Rata- } \\
\text { rata }\end{array}$ & Maks & Min \\
\hline Kontrol & 60,70 & 87,5 & 27,50 \\
\hline $\begin{array}{c}\text { Eksperime } \\
\mathrm{n}\end{array}$ & 75,88 & 93,75 & 53,15 \\
\hline
\end{tabular}

\section{a. Uji Normalitas}

Uji normalitas menggunakan uji Kolmoogorof_SmirnovZ denganbantuan software SPSS 18 diperoleh hasil yaitu nilai sig $\alpha=0,200$ sedangkan nilai sig untuk kelas eksperimen yaitu 0,135 . Berdasarkan kriteria pengujian nilai sig $>\alpha 0,05$ maka data berdisktribusi normal.

\section{b. Uji homogenitas}

Pengujian homogenitas menggunakan uji Fdiperoleh nilai $F_{\text {hitung }}=1,684$ dan nilai $F_{\text {tabel }}=$
1,84. Karena nilai $F_{\text {hitung }}<\mathrm{F}_{\text {tabel }}$ maka kriteria pengujian maka $\mathrm{H}_{0}$ diterima. Dan pengujian menggunakan SPSS diperoleh sig $=0,194$. Berdasarkan kriteria pengujian sig $>\alpha=0,05$ maka data dikatakan homogen. Jadi dapat disimpulkan bahwa nilai posttest kelas eksperimen dan kelas kontrol homogen.

\section{c. Pengujian Hipotesis}

Pengujian hipotesis menggunakan uji $t$ diperoleh bahwa nilai $t_{\text {hitung }}=6,269$ dan nilai $t_{\text {tabel }}=1,998$. Karena nilai $t_{\text {hitung }}>t_{\text {tabel }}$ berdasarkan kriteria pengujian maka $\mathrm{H}_{0}$ ditolak. Pengujian menggunakan SPSS diperoleh nilai signifikan sebesar ,000< 0,05 . Jadi dapat disimpulkan bahwa terdapat perbedaan yang signifikan antara rata-rata hasil belajar siswa dengan menggunakan model pembelajaran think talk writedan pembelajaran ekspositori di kelas VII SMP Negeri 15 Kota Bengkulu.

\section{Pembahasan}

Pada penelitian ini untuk mengukur hasil belajar siswa. Dari hasil belajar siswa berdasarkan nilai posttest terlihat bahwa nilai rata-rata kelas eksperimen lebih tinggi dari kelas kontrol. Hal tersebut dipengaruhi oleh perbedaan model pembelajaran yang diterapkan pada kelas tersebut.

Model pembelajan yang diterapkan pada kelas eksperimen yaitu model pembelajaran think talk write sedangkan kelas kontrol dengan pembelajaran ekspositori. Dengan model pembelajaran think talk write, siswa diminta untuk menyelesaikan masalah pada LKPD tentang materi aritmetika sosial. LKPD tersebut berisikan tahap-tahap yang terdiri dari tahap think, talk, write, kesimpulan dan latihan. Melalui proses pada tahap think, siswa terlebih dahulu membaca masalah yang diberikan kemudian siswa akan berpikir untuk menyelesaikan masalah yang diberikan sehingga siswa harus membaca LKPD tersebut secara individu. Aktivitas berpikir yang dilakukan siswa secara individu adalah menentukan hal yang diketahui dari masalah yang diberikan dan mencari solusi berdasarkan pengetahuannya. Pada pertemuan pertama, siswa masih mengalami kesulitan dalam menyelesaikan tahap think karena masih 
kurangnya pengetahuan siswa tentang yang dipelajari.

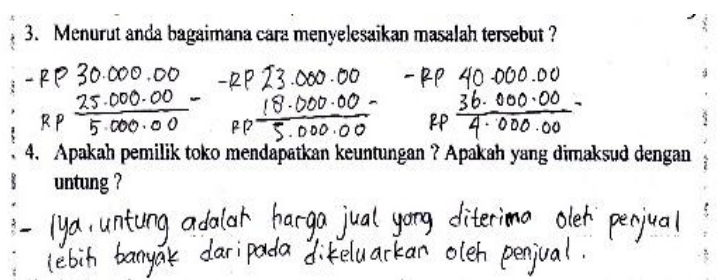

\section{Gambar 1 Jawaban LKPD Tahap Think}

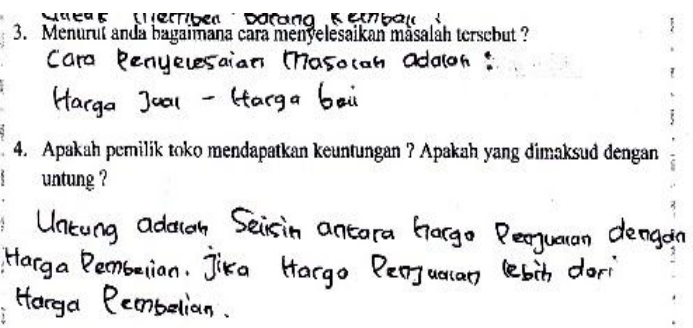

\section{Gambar 2Jawaban LKPD Tahap Think}

Dari gambar 1 dan gambar 2 yang merupakan jawaban siswa pada LKPD tahap think terlihat perbedaan jawaban yang diberikan siswa karena siswa menyelesaikan tahap think tersebut secara individu berdasarkan pengetahuannya sendiri.

Setelah tahap think, siswa diminta untuk melanjutkan LKPD tahap talk. Melalui tahap talk, siswaakan berdiskusi dengan anggota kelompok untuk menentukan penyelesaian masalah yang diberikan. Dengan adanya diskusi kelompok, siswa akan lebih terbantu dengan saling bertukar pendapat sehingga menemukan solusi dari masalah yang diberikan.Pada pertemuan pertama ada kelompok yang pelaksanaan diskusinya belum terlalu berjalan karena siswa belum terbiasa melakukan diskusi kelompok sehingga guru harus membimbing pada saat diskusi kelompok berjalan.

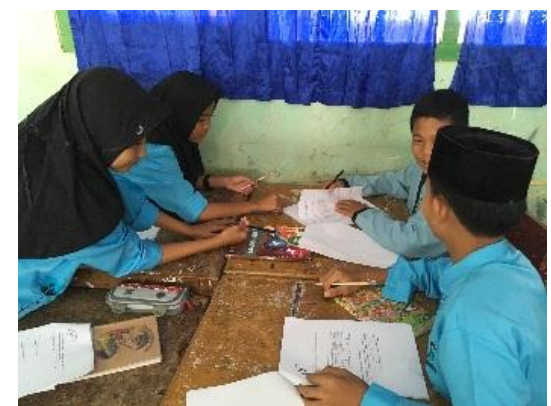

Gambar 3 Aktivitas pada Tahap Talk

Gambar 3 merupakan aktivitas yang dilakukan siswa pada tahap talk. Terlihat bahwa kelompok tersebut mulai termotivasi untuk berdiskusi dengan kelompoknya dan saling bekerja sama selama diskusi.

Setelah tahap think dan talk dilaksanakan, siswa diminta melanjutkan LKPD tahap write. Siswa menuliskan kembali hasil diskusinya dengan menggunakan bahasa sendiri. Sehingga pada tahap ini terlihat sejauh mana pengetahuan siswa setelah berdikusi dengan kelompoknya dan juga membantu siswa untuk menghubungkan pengetahuan yang dimiliki dengan hasil diskusi yang telah dilakukan. Beberapa siswa masih mengalami kesulitan untuk menuliskan kembali hasil diskusinya sehingga beberapa siswa masih membutuhkan bantuan dari guru untuk menuliskan hasil diskusinya.

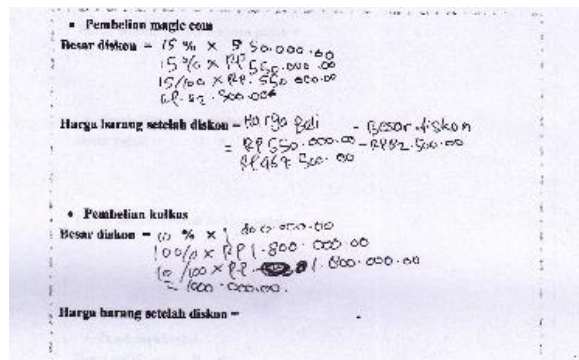

\section{Gambar 4 Jawaban LKPD Tahap Write}

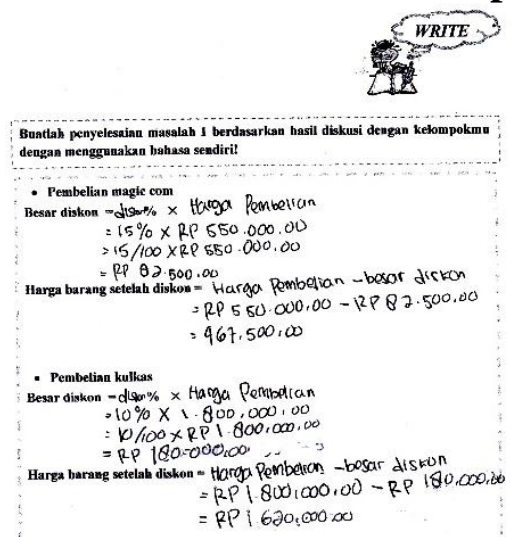

Gambar 5Jawaban LKPD pada Tahap Write

Berdasarkan gambar 4 dan gambar 5 terlihat bahwa terdapat perbedaan jawaban siswa dalam menyelesaikan LKPD tahap write. Ada siswa yang masih belum lengkap menyelesaikan LKPD karena kesulitan untuk menuliskan hasil diskusi kelompoknya. Dan ada siswa yang telah memberikan jawaban LKPD dengan lengkap. Perbedaan jawaban siswa dikarena siswa menyelesaikan LKPD tahap write secara individu sesuai hasil diskusi kelompok masing-masing. 
Setelah semua tahap think, talk dan write dilaksanakan. Siswa diminta untuk membuat kesimpulan berdasarkan kegiatan yang dilaksanakan. Kemudian siswa diminta untukmenyelesaikan latihan pada LKPD untuk mengetahui sejauh mana pengetahuan siswa terhadap materi yang dipelajari. Pada akhir model pembelajaran think talk write terdapat tahap presentation. Pada tahap ini, setiap kelompok dapat saling bertukar pendapat saat diskusi kelas. Dengan adanya pelaksanaan diskusi kelas akan membantu siswa memperdalam pengetahuannya tentang materi yang telah dipelajari sehingga tidak terjadi kesalahan dalam proses menerima pelajaran.

Pada kelas kontrol, proses pembelajaran didominasi oleh guru sehingga membuat siswa menjadi kurang aktif dalam proses pembelajaran dan terpaku oleh materi yang disajikan guru.Pembelajaran ekspositori dimulai dari tahap penyampaian materi oleh guru ke siswa, sehingga pada tahap ini siswa hanya memperhatikan penjelasan guru. Setelah menyampaikan materi, guru melanjutkan dengan contoh soal. Contoh soal tersebut diselesaikan oleh guru dan siswa kebanyakkan hanya melihat guru menyelesaikan soal.Setelah guru memberikan contoh soal, siswa diminta untuk mencatat materi dan contoh soal yang telah dikerjakan. Ketika mencatat, siswa diarahkan untuk membuat kesimpulan. Untuk melihat kemampuan siswa menerapkan materi yang diperolehnya, guru meminta siswa untuk menyelesaikan latihan yang berkaitan dengan materi yang diberikan.

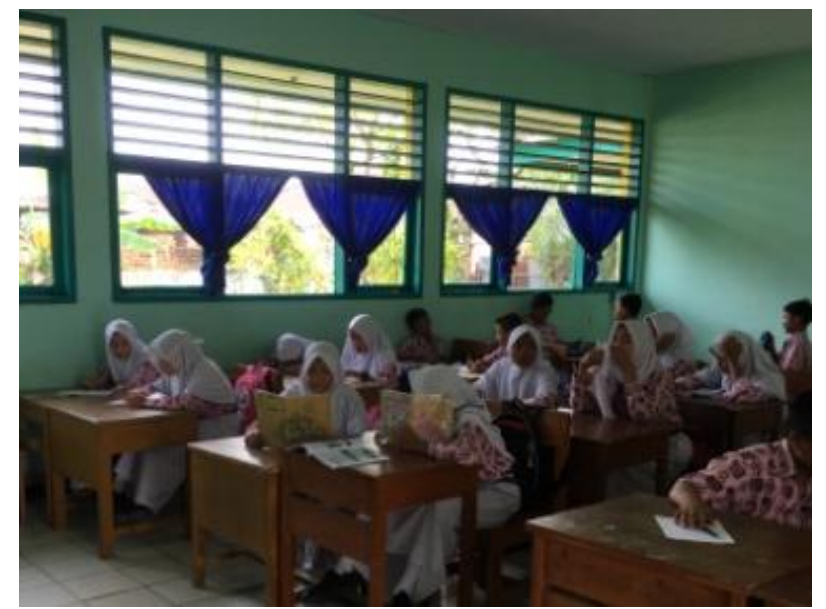

Gambar 6 Aktivitas Siswa Kelas Kontrol
Dari gambar 6 dapat dilihat pada saat siswa diminta untuk menyelesaikan latihan yang diberikan, kebanyakkan siswa sangat terpaku dengan contoh soal yang diberikan guru. Dan membuat siswa kesulitan dengan soal yang berbeda dengan contoh yang diberikan karena siswa hanya melihat contoh soal yang telah guru. Pada pelaksanaan pembelajaran ekspositori hanya ada beberapa siswa yang aktif selama proses pembelajaran dan sebagian siswa hanya mengamati penjelasan materi yang disampaikan oleh guru. Sehingga pengetahuan yang diperoleh siswa hanya sebatas yang disampaikan guru dan juga siswa yang tidak mengerti dengan materi yang disampaikan hanya diam. Hal tersebut berpengaruh pada hasil belajar siswa kelas kontrol. Pengetahuan yang dimiliki siswa hanya tentang materi yang disajikan olehguru, walaupun ada beberapa siswa yang aktif bertanya untuk memperdalam pengetahuannya.

Berdasarkan proses pembelajaran siswa kelas kontrol dan kelas eksperimen maka dapat terlihat perbedaan. Sehingga mempengaruhi kemampuan siswa menjawab posttest. Siswa kelas eksperimen sudah terbiasa menuliskan jawaban secara lebih rinci, teratur dan jelas karena siswa kelas eksperimen terbiasa mengerjakan LKPD dengan tahap think, talk, write secara individu dan kelompok sehingga siswa menemukan sendiri konsep yang dipelajari. Perbedaan inilah yang membuat hasil belajar siswa khusunya pada kemampuan pemahaman konsep siswa kelas eksperimen lebih baik dari kelas kontrol.Melalui model pembelajaran think talk writehasil belajar siswa lebih meningkat dikarenakan setiap proses pada model pembelajaran tersebut membantu siswa untuk lebih aktif menemukan dan memahami pengetahuannya sehingga mempermudah siswa dalam menyelesaikan soal yang diberikan siswa.

Dari uraian diatas dapat dilihat bahwa terdapat perbedaan hasil belajar siswa yang signifikan antara model pembelajaran think talk write dan ekspositori yaitu hasil belajar siswa dengan model pembelajaran think talk write lebih baik dari pembelajaran ekspositori. Hal tersebut sejalan dengan hasil pengujian hipotesis diperoleh bahwa terdapat perbedaan 
yang signifikan antara rata-rata hasil belajar siswa dengan menggunakan model pembelajaran think talk writedan pembelajaran ekspositori di kelas VII SMP Negeri 15 Kota Bengkulu.

\section{PENUTUP}

\section{Simpulan}

Berdasarkan hasil analisis data dengan pengujian hipotesis menggunakan uji-t diperoleh nilai $t_{\text {hitung }}=6,269$ dan nilai $t_{\text {tabel }}=$ 1,998. Karena kriteria pengujian $t_{\text {hitung }}>t_{\text {tabel }}$ maka $\mathrm{H}_{0}$ ditolak. Dengan nilai rata-rata posttestsiswa siswa kelas kontrol $=60,70$ dan kelas eksperimen $=75,88$. Jadi dapat disimpulkan bahwa terdapat perbedaan yang signifikan antara rata-rata hasil belajar siswa dengan menggunakan model pembelajaran think talk writedan pembelajaran ekspositori di kelas VII SMP Negeri 15 Kota Bengkulu pada materi aritmetika sosial.

\section{Saran}

Berdasarkan hasil penelitian yang telah dilakukan, maka saran yang dapat diberikan adalah :

1. Agar model pembelajaran think talk write meningkatkan hasil belajar siswa sebaiknya pada tahap think sebaiknya guru meminta siswa membawa minimal 2 buku bacaan sebagai referensi agar siswa dapat mengikuti pelajaran dengan maksimal

2. Agar diskusi dapat berjalan dengan baik sebaiknya guru selalu memberikan motivasi kepada siswa untuk tidak

3. Agar tahap write dapat tercapai secara maksimal sebaiknya guru selalu mengingatkan siswa pada tahap sebelum untuk serius mengikuti proses belajar di kelas sehingga tidak kesulitan menyelesaikan tahap ini

\section{DAFTAR PUSTAKA}

Dimyati dan Mudjiono. 2013. Belajar dan Pembelajaran. Jakarta: Rineka Cipta.

Hamdayama, Jumanta. 2015. Model dan Metode Pembelajaran Kreatif dan Berkarakter. Bogor: Ghalia Indonesia.

Russefendi, H.E.T. 2006. Pengantar Kepada Membantu Guru Mengembangkan dalam Pengajaran matematika untuk Meningkatkan CBSA. Bandung: PT Tarsito Bandung.

Sanjaya, Wina. 2014. Strategi Pembelajaran Berorientasi Standar Proses Pendidikan. Jakarta: Kencana Prenadamedia Group.

Shoimin, A. 2016. 68 Model Pembelajaran innovatif dalam Kurikulum 2013. Yogyakarta: Ar-Ruzz Media.

Sudjana, Nana. (2009). Penilaian Hasil Proses Belajar Mengajar. Bandung : Remaja Rosdakarya.

Sugiyono. 2014. Metode Penelitian Kuantitatif, Kualitatif dan $R \& D$. Bandung: Alfabeta.

Yamin, Martini dan Ansari, Bansu. 2012. Taktik Mengembangkan Kemampuan Individual Siswa. Ciputat: Referensi (GP Press Group) 